\title{
Characterization of Technical Production System of Kindirmou, a Fermented Local Milk Product from Cameroon
}

\author{
Esther Biaton Njeufa*, Hélène Carole Edima and Robert Ndjouenkeu \\ Department of Food Science and Nutrition, University of Ngaoundéré, \\ PO Box 455 Ngaoundéré, Cameroon \\ *Corresponding author
}

\section{Keywords}

Kindirmou, local dairy product,

Adamawa,

Cameroon

\section{Article Info}

\section{Accepted:}

12 May 2021

Available Online:

10 June 2021
The characterization of the technical practices involved in the production of kindirmou constitutes a key element in its valorization. Assuming that the quality of the kindirmou is based on the specific practices to the territory, an analysis of the technical practices of the kindirmou in relation with the quality was carried out in the Adamawa region of Cameroon. The holistic approach of the survey including a technical and socio-economic diagnosis of the production of kindirmou, the modes of perception and management of the quality of the products by the actors, the characterization of the technological quality of the product and the orientations of the system was carried out in the five Divisions of Adamaoua Region (Ngaoundéré, Meiganga, Tibati, Banyo and Tignère) from April to October 2016. The mains result show that, $96 \%$ of the actors involved in the kindirmou production chain are located in town. $97 \%$ are Fulani with $70 \%$ women. The milk is directly milked for $63 \%$ or purchased for $37 \%$. According to the material involve in the production of kindirmou, $9 \%$ is made of wood, $46.5 \%$ of plastic, $43.2 \%$ of stainless steel and $1.3 \%$ of stainless. The fermentation is spontaneous, according to the starter used, $65.6 \%$ is pendidam, $30.3 \%$ kindirmou, $4.1 \%$ unwashed lebol. As far as the valorization of Kindirmou is concerned, the technical production system has been characterized, but it appears that good hygiene and manufacturing practices are not applied by the actors and the microorganism involved in the fermentation are unowned.

\section{Introduction}

Kindirmou is a local dairy product, resulting from the spontaneous fermentation of non-skimmed milk. It was originally produced and consumed by the mainly pastoral Fulani peoples of the northern savannas of Cameroon. This product originates from a need to preserve milk, which cannot be stored for more than 24 hours in a cool place, conditions that these peoples cannot meet.

In addition, fermentation facilitates the conservation of milk, promotes the development of organoleptic and nutritional 
characteristics highly appreciated consumers (Balla, 2011; Libouga, 2002).

However, the valorization of kindirmou remains limited by sanitary quality of the product (Edima et al., 2014; Libouga et al., 2005). This variability in quality would come mainly from production conditions.

Indeed, if the control of fermentation implies the control of the bacterial strains involved, it is important to note that the uncontrolled conditions of the peasant practices of fermentation, in terms of body hygiene and the environment, as well as precarious conditions of preservation, encourage the involvement of microbial contamination strains, with the consequence of limiting the sanitary quality of the product, or even its rapid deterioration.

Given that the technical practices of food production and processing are generally associated with a territory, in terms of the functional organization of actors and techniques, as well as networks of relationships for the development of local resources, which is why they are qualified of localized food systems (Muchnik et al., 2007), we can, in the context of kindirmou production, consider that it is indeed a localized food system. In addition, the territory would also be a factor of variability in technical practices and therefore in the quality of products. It can therefore be assumed hypothetically that the production practices of kindirmou vary from one space to another, in terms of hygienic conditions and risks of contamination, which would justify a variability in the quality of the product (Nduko, 2016; Jans et al., 2017).

Based on this assumption, this aims of this work is to describe the production system of kindirmou in the different production spaces of the Adamawa Region.

\section{Material and Methods}

\section{Area of study}

The study was carried out in the form of a survey in the five Divisions of the Adamawa Region, with focus on markets and production sites of the administrative centers and their suburbs, areas par excellence of convergence of products for consumption (Fig. 1).

Five towns (administrative centers) (Ngaoundéré, Meiganga, Banyo, Tibati, Tignère) and 28 villages/districts surrounding these towns were thus visited.

\section{Approach of the study}

The study was conducted using a holistic and integrated approach including (Ndjouenkeu, 2018; Dairou et al., 2014) (Fig. 2):

A technical and socio-economic diagnosis of kindirmou production: typology of actors (gender, ethnicity, social and economic levels, etc.) and technical practices (tools, technics, processing organization and management, etc.)

The perception and management modes of product quality by the actors,

The characterization of the technological quality of the product, through their $\mathrm{pH}$ measurements. And finally, the orientations for controlling the technical system, on the basis of a link between the perception and management of the quality of the product and its technological attributes.

\section{Implementation of the study}

The survey was conducted as an open interview with kindirmou producers and 
sellers. These actors were identified with the support of local administrative services of agriculture and contacted on the markets from their sale points or in their production workshops.

The visit to the production workshops also allowed the interview to be carried out while identifying the main production tools, as well as the details of the actors' practices and their purpose. All actors were interviewed individually.

Thus, a total of 110 actors were interviewed in the five towns and their surroundings, including: 31 actors in Ngaoundéré, 32 in Meiganga, 23 in Banyo, 16 in Tibati and 8 in Tignère.

The interviews were conducted on a conversational basis, using an interview guide incorporating:

The identification of the people involved in the production (sex, ethnic origin, etc.)

The origin of the milk and / or its method of collection

Any pre-treatment of the milk before its processing into kindirmou

The kindirmou production process

Indicators of the perception of product quality from the raw material to the final product

Quality constraints during production

The mechanisms put in place by the actors to guarantee the quality of their product or in response to the constraints encountered.

The methods, tools and conditions of kindirmou conservation
Evaluation of good hygiene and manufacturing practices of kindirmou

In order to evaluate the application of good hygiene practices and good manufacturing practices in the manufacturing process of kindirmou, a Check list designed according to the Alimentarius codex (FAO / IDF, 2012) was applied on 110 kindirmou producers surveyed.

\section{Statistical analyzes}

The data collected during the interviews and checklist were translated into modalities of which frequencies were analyzed using Sphinx ${ }^{+2}$ V.5 survey software.

\section{Determination of $\mathrm{pH}$ and titrable acidity of the kindirmou}

Kindirmou samples were randomly collected from the survey sites depending on the type of ferment used for fermentation, and analyzed on site for their $\mathrm{pH}$, the main indicator of the level of fermentation of the product by using method of Siboukeur (2007).

\section{Results and Discussion}

Actors involved in the kindirmou production

The production of kindirmou is characterized by female dominance $(\geq 70 \%)$, particularly among the Fulani who constitute the majority ethnic group in the activity (Fig. 3). The Fulani socio-cultural group constitutes more than $97 \%$ of the actors of the technical production system, with a marginal involvement $(<3 \%)$ of other ethnic groups (Hausa, Moufou, Dii) constituted mainly of men. The female dominance in the activity could be attributed to the fact that the production of "kindirmou" is above all a domestic activity devolved to women (Sow, 2005; Edima et al., 2014), the kindirmou produced being 
initially intended for family consumption. However, these actresses are also the least educated social fringe, with barely $10 \%$ above primary school level (Fig. 3b).

The involvement of men in the activity is observed mainly in urban areas where the activity is economically promising (Fig. 4), which confirms the tendency to masculinization of production activities when they are economically promising (GuétatBernard, 2015).The migration of populations and urbanization inherent in the creation, in the eighties, of new administrative units (Regions, Divisions, Sub-divisions), and in the influx of civil servants, have fostered the development of a commercial activity in which local products, like kindirmou, are integrated, thus giving housewives the opportunity to sell on these markets, the surpluses of family production. Men, following significant market opportunities, are mainly present in the running of dairy bars. Women, on the contrary, distribute their products on shelves, in the open air or in the shade of trees. The male presence, significant in Ngaoundéré, Meiganga and Banyo (Fig. 4), is mainly due to the predominantly urban status of these localities, which makes them to constitute the point of convergence of the economic activities of the Region and, because of their geographical position, they are the main transit stops on the road linking the northern and southern regions of the country, which generates an attractive commercial activity for men. On the contrary, Tibati and Tignère, relatively isolated, have practically a village status, where the activity is predominantly peasant, the food market being carried by women who market the surpluses of household production.

The ethnic distribution of the actors in the different production areas (Fig. 4) shows that the Fulani are dominant in all the production areas. However, production areas such as Meiganga, Tignère and Tibati are represented exclusively by the Peuls, as opposed to Ngaoundéré and Banyo, which represents an ethnic heterogeneity. This suggests the strategic influence of these two areas in the trading system of the Adamawa region. Indeed, Ngaoundéré is the regional capital of the Region and therefore constitutes the point of convergence of the economic activities of the Region. Besides, Banyo because of its geographical position connecting the northern regions to the southern regions of the country.

\section{Good hygiene and manufacturing practices of kindirmou}

The kindirmou producers use milk from manual milking regardless of its origin (direct milking or purchase) with a break in the cold chain. $100 \%$ producers do not master hygiene of the kindirmou processing and assessment of kindirmou processing. 90\% of producers are non-compliant to the reglementation by using wooden, plastics and enamel material. These observations show the non-compliant nature of the implementation of good hygienic manufacturing practices for kindirmou in the Adamoua region according to the recommendations of the Codex Alimentarius which can have a consequence on the microbiological and technological aspect of kindirmou (Table 1).

This result shows that personnel can be a source of product contamination. This had already been presented in the literature, resulting in the appearance of food poisoning (FAO, 2007; Libouga et al., 2005; Edima et al., 2014).

These observations show that $90 \%$ of the materials used are non-regulatory. These materials can interact with the kindirmou and 
promote its contamination (Gaquerel and Costes, 2004). The use of plastic containers is the result of recycling of packaging mineral water, cooking oil and hydrocarbon products.

However, this container can be source of chemical contamination of milk due the exchange and the transfer of chemical into the milk, and also a biological contamination due to the structure of the container which cannot be easily cleaned and disinfected (Edima et al., 2014).

Enamel materials when they are crumbled, the metal compounds can react with the acids present in the kindirmou, causing the formation of hydrogen gas and metal ions which will lead to a phenomenon of corrosion with the appearance of a metallic taste as well than perforation of the material (Martinez, 2002).

Wooden materials have a porous structure, are fragile and easily cracked. They are materials of questionable hygienic qualities, favorable to physical contamination and proliferation of microorganisms in the kindirmou (Gran et al., 2002).

Evaluation of the hygiene of kindirmou processing milieu shows a lack of a production area, presence of wastes that can be liquid or solid that can constitute potential sources of food contamination, namely flies which are truly formidable agents. Evaluation of the kindirmou transformation method reveal the use of an undefined starter composition would be a source of contamination of kindirmou, because they are not produced under hygienic conditions according to the literature (Edima et al., 2014). In addition, failure on fermentation time and temperature could be a consequence of variation in organoleptic quality of kindimou depending on the production areas.

\section{Technical practices of kindirmou production}

\section{Milk supply and processing level}

Kindirmou actors value chain are found in the three links of the chain (production, processing and distribution). The milk used in the manufacture of kindirmou comes either from direct milk milking $(63 \%)$ or by purchase $(37 \%)$. In this distribution of supply, the Fulani derive more than $61 \%$ of their raw material from trafficking compared to $1.6 \%$ for other ethnic groups (Fig 8). The small number of Hausa $(0.8 \%)$ and Dii $(0.8 \%)$ involved in the production of kindirmou $(0.8 \%)$, are exceptionally because they have become breeders and therefore derive their raw material from milking. of their cows. Purchase milk could be an initiative by stakeholders to meet growing demand for kindirmou. However, purchasing is not always obvious. Indeed, the low availability of farmer's milk, inherent in the difficulties of acquiring milk with regard to the breeds involved, which are generally lactating and non-dairy, accentuated by the difficulties of access to farms due to poor road conditions. This would better explain the financial and production constraints of local dairy products noted by Edima et al., (2013). Seen on this aspect, these constraints would minimize the market opportunities for kindirmou, a product however sought after by consumers (Libouga, 2005, Libouga et al., 2010). However, it should be noted that the purchase of milk under peasant conditions where the cold chain is not controlled remains a risky initiative for controlling the microbiological quality of milk (Colloque ocha, 2010).

The production of kindirmou for the market is the priority destination of milk, since the response to consumer demand and the profit function constitute, for nearly $70 \%$ of the actors, the justification for the acquisition of 
milk, irrespective of its personal milking or purchase origin. This destination is valid regardless of the ethnic origin of the actors. However, we note among the Fulani that the transformation of milk into kindirmou, in addition to having economic assets, constitutes a cultural identity. In addition, the ethnic groups (Hausa, Moufou and Dii) do it only for marketing. This confirms the cultural dimension of the uses of milk in Fulani communities (Duteurtre, 2019).

The transformation of milk into kindirmou seems ethno-specific, as the Fulani are the ethnic group most involved in the activity. The milk intended for the processing of kindirmou is transported to the manufacturing workshop by imprinting either a vehicle (car / motorcycle / bicycle) (28.8\%), or walking (71.2\%) over more kilometers or less important. However, according to Edima et al., (2012), these modes of transport at room temperature in the absence of a cold chain compromise the hygienic quality of the milk. It should be noted that, women transport the milk on the head and by foot, from the milking place to the processing workshop. These findings help to strengthen the artisanal nature of the kindirmou production activity.

\section{The processing of milk into kindirmou}

Usually, milk is processed within 2 hours after acquisition. This period can be spread out according to the collateral occupations of the actors, in particular women, involved in various household tasks which are likely to delay the processing of milk.

For all stakeholders, the conditions for transporting milk to the processing plant, as well as the constraints imposed by the relationship with the supplier (order confirmation, delivery time, etc.) can also be factors in processing delays.
The transformation of milk into kindirmou follows a process in four major steps (Fig. 5) integrating: the filtration of the milk, its heat treatment, its cooling and its fermentation.

The processing tools are of the household type (calabash, plastic bucket, enamel or stainless-steel bowl) and serve as both fermentation reactors and kindirmou conditioning and distribution equipment, with variable volumes depending on the production level. For this purpose, the calabash is only used by women and regulatory stainless-steel equipment, particularly by men. This could be associated with the level of education of men and their involvement in the implementation of different governmental milk projects and programs, which trained the actors of the local milk system and strongly contributed to the emergence of dairy bars in the cities (Ndjouenkeu et al., 2003). In general, plastic and enamel materials are mainly used because of their affordable cost on the markets, followed by the calabash. All these materials are very often, sources of chemical, microbiological and physical contamination (Gaquerel et Costes, 2004, Gran et al., 2002;), due to the risk of their constituent elements being diffused into the dairy matrix and their ability to concentrate milk microorganisms on their surface.

The milk can be heated over a wood fire, an oil stove or a gas hob depending on the social level of the actors. Women mainly use wood fires ( $68 \%$ of actresses), unlike men who use kerosene and gas hobs. This could be justified by the fact that men produce kindirmou in urban dairy bars, while women generally do it at the domestic level in their kitchen (Sow, 2005; Edima et al., 2014).

Filtration of milk before processing is seen as a classic and common operation intended to 
rid the milk of physical contaminants (flies, cow fur, etc.), particularly for milk directly from milking.

The majority of actors ( $>90 \%$ ) heat the milk to boiling, with objectives to sanitize it and to obtain a good quality kindirmou. Such a practice is liable to degrade milk proteins with foreseeable consequences on the nutritional and functional quality of the final product. It should be noted that boiling heating is practiced overwhelmingly (>70\% of citations) by women who, perhaps due to their low level of education, have not benefited from government training projects and programs.

After heating, the milk is allowed to cool at room temperature. To speed up the cooling which, in a steady situation can last up to 2 hours, some actors stir by repeated transfers, with sufficient spacing between the transfer basins, thus allowing ventilation of the product. While this operation actually speeds up the cooling of the milk, it exposes it, on the other hand, to a risk of microbial recontamination by the ambient air, which may justify previous findings on the doubtful microbiological quality of milk and its products sold on the markets of the region (Libouga et al., 2005; Edima et al., 2014).

Fermentation, a central and critical unit operation in the production of kindirmou

Fermentation, the operation of acidifying milk to transform it into kindirmou, consists either in letting the milk ferment spontaneously, or in inoculating it with kindirmou from a previous production, in particular from the day before (oldkindirmou), pendidam, or unwashed lebol (partially dehydrated fat, obtained by churning milk cream), and to let it stand at room temperature for about 3 to 24 hours. These different ferments are all products derived from kindirmou with the fundamental difference being their degree of acidity (Fig. 6). They are made by the actresses of the production of kindirmou, in the dynamic of artisanal production of dairy products. Pendidam is the product of further fermentation of skimmed or nonskimmed kindirmou, and is the most conservable form of fermented milk, due to its higher acidity, a characteristic inherent in the presence of acidophilic lactic acid bacteria that seems not to exist in kindirmou (Jiwoua and Millière, 1990). When kindirmou is skimmed (by scraping off the cream covering its surface), it provides bourwadam (skimmed and stirred fermented milk), another product from the range of local fermented dairy products, which is then stirred and fermented to result in pendidam. Lebol, an aggregate of fat considered in popular language as traditional butter, results from churning cream, the buttermilk of which is fermented into pendidam. The use of unwashed lebol as a ferment is due to the fact that at this stage, it would contain residual strains capable of initiating fermentation. The ferments are inoculated at a rate between 0.5 and $1.75 \mathrm{ml}$ of ferment per litter of milk. Milk is inoculated, either in bulk or in small pots or cups of volume corresponding to individual consumption portions. The temperature and fermentation time are managed in an intuitive and personalized way by the actors, due to the lack of suitable control tools. The temperature is evaluated by appreciating the touch of the milk which must be, in the words of the actors, "lukewarm like water exposed to the sun, or like the child's porridge". Failure to control the temperature induces a variability in the duration of the fermentation (3-24 hours), especially since the process takes place at room temperature, which is itself susceptible to variation. The term of fermentation is defined according to the operator's perception of the kindirmou quality. 
The quality of kindirmou: perception, management and technological value

The quality attributes sought by those involved in the production of kindirmou mainly relate to the color, texture and taste of the product (Fig. 7). Good quality kindirmou should have a whitish color ("matt white"), a homogeneous gel and should not be acid. These attributes are perceived in equivalent proportions regardless of the production site, which may be indicative of a relative homogeneity in the perception of the quality of kindirmou throughout its cultural space. In addition, the "non-acid" taste of kindirmou is the characteristic that differentiates this product from other traditional fermented milks, pendidam in this case. The "homogeneous gel" or "heavy" character of its texture is in fact representative of the translation of the term kindirmou (heavy milk) into the Fulani language (Libouga et al., 2005; Essomba et al., 2002). The matt white (or whitish, even yellowish) color of kindirmou is related to to the $\beta$-carotenoid content in the milk fat, which depends on the cow's diet. Indeed, at the end of fermentation, the fat in the milk forms a thin shiny layer on the surface of the product, in particular when the fermentation has been undergone without previous mixing of milk, giving it a yellowish appearance. Stirring the product when it is packaged or at the time of consumption, gives the matt white color. The fat, combined with the firm texture of kindirmou, gives the product its softness when consumed, which actors and consumers translate as the "oily sensation in the mouth". This quality characteristic justifies the operation of mixing kindirmou which, in order to both homogenize the product and reduce the size of the fat globules, changes its appearance and promotes the sensation of softness in the mouth.

The non-occurrence of the above attributes reflects a poor quality of kindirmou, which is characterized by a foamy appearance, phase separation and above all, an acid taste (Fig. 8). These non-conformities reflect a technical malfunction in production practice, in particular in terms of management of hygiene, heating temperature and fermentation parameters of the milk. Indeed, poor hygienic conditions (environmental and bodily) are likely to favor the development of hetero-fermentative contamination germs, often non-lactic, of fecal or telluric origin (Mahaut et al., 2005; Federighi et al., 2005), resulting in the foamy appearance and phase separation (whey exudation) of the product. The uncontrolled fermentation inherent in the coupling between the contamination germs and endogenous bacteria of technological interest, will result in high acidification of the product (Laithier et al., 2004).

Table.1A Application of good hygienic and good manufacturing practices by actors

\begin{tabular}{|c|c|c|}
\hline Requirements & Conform & Non conform \\
\hline Hand washing before and after handling & & $\checkmark$ \\
\hline Wearing clean and suitable clothing & & $\checkmark$ \\
\hline Wearing jewelry during handling & & $\checkmark$ \\
\hline Wearing a mouth-nasal mask & & $\checkmark$ \\
\hline Medical visit every 6 months & & $\checkmark$ \\
\hline Total of scores & & $100 \%$ \\
\hline
\end{tabular}


Table.1B Evaluation of the hygiene of the kindirmou processing equipment

\begin{tabular}{|c|c|c|}
\hline Requirements & Conform & $\begin{array}{c}\text { Non } \\
\text { conform }\end{array}$ \\
\hline Use of wooden materials & & $\boldsymbol{V}$ \\
\hline Use of plastic materials & & $\boldsymbol{V}$ \\
\hline Use of enamel material & & $\checkmark$ \\
\hline Use of stainless steel materials & $\checkmark$ & \\
\hline Washing and disinfection of equipment before and after & & $\boldsymbol{V}$ \\
\hline Use of materials only for production & & $\boldsymbol{V}$ \\
\hline Total of scors & $10 \%$ & $\mathbf{9 0 \%}$ \\
\hline
\end{tabular}

Table.1C Evaluation of the hygiene of kindirmou processing milieu

\begin{tabular}{|c|c|c|}
\hline Requirements & Conform & $\begin{array}{c}\text { Non } \\
\text { conform }\end{array}$ \\
\hline Existence of a production area & $\checkmark$ \\
\hline Respect for forward movement & $\checkmark$ \\
\hline Presence of pests & $\checkmark$ \\
\hline Presence of a waste disposal system & $\checkmark$ \\
\hline Cleaning and disinfection of production areas & & $\checkmark$ \\
\hline Easily washable premises, materials and surface & & $\boldsymbol{V}$ \\
\hline Total of scors & $100 \%$ \\
\hline
\end{tabular}

Table.1D Evaluation of the kindirmou transformation method

\begin{tabular}{|c|c|c|}
\hline Requirements & Conform & $\begin{array}{c}\text { Non } \\
\text { conform }\end{array}$ \\
\hline Heat treatment of milk & $\checkmark$ & \\
\hline Respect of the time / temperature of heating the milk & & \\
\hline Rapid cooling of heat-treated milk & & $\checkmark$ \\
\hline Control of fermentation temperature & & $\checkmark$ \\
\hline Use of controlled ferments & & $\checkmark$ \\
\hline Respect of the storage temperature & & $\boldsymbol{V}$ \\
\hline Total of scores & $10 \%$ & $\mathbf{9 0 \%}$ \\
\hline
\end{tabular}


Table. $2 \mathrm{pH}$ of the kindirmou depending on the manufacturing site and the type of ferment used

\begin{tabular}{|c|c|c|c|}
\hline Localities & \multicolumn{3}{|c|}{ Type of ferment } \\
\hline & Old kindirmou & Pendidam & Unwashed Lebol \\
\hline Tignère & $4.80 \pm 0.08^{\mathrm{aA}}$ & $4.91 \pm 0.17^{\mathrm{aA}}$ & - \\
\hline Banyo & $4.56 \pm 0.03^{\mathrm{aB}}$ & $4.60 \pm 0.22^{\mathrm{aA}}$ & - \\
\hline Tibati & $4.93 \pm 0.06^{\mathrm{aA}}$ & $4.54 \pm 0.08^{\mathrm{bB}}$ & - \\
\hline Meiganga & $4.49 \pm 0.12^{\mathrm{aB}}$ & $4.54 \pm 0.04^{\mathrm{aB}}$ & $\mathbf{4 . 6 5}^{\mathrm{a}}$ \\
\hline Ngaoundéré & $\mathbf{4 . 7 7} \pm \mathbf{0 . 1 6}^{\mathbf{a A}}$ & $\mathbf{4 . 8 4} \pm \mathbf{0 . 0 5}^{\mathbf{a A}}$ & - \\
\hline
\end{tabular}

$a$, $b$ : the means showing the same lowercase letters on the same line are not significantly different at $p=0.05$

$A, B$ : the means showing the same letters in upper case in the same column are not significantly different at $p=$ 0.05

Fig.1 Area of study

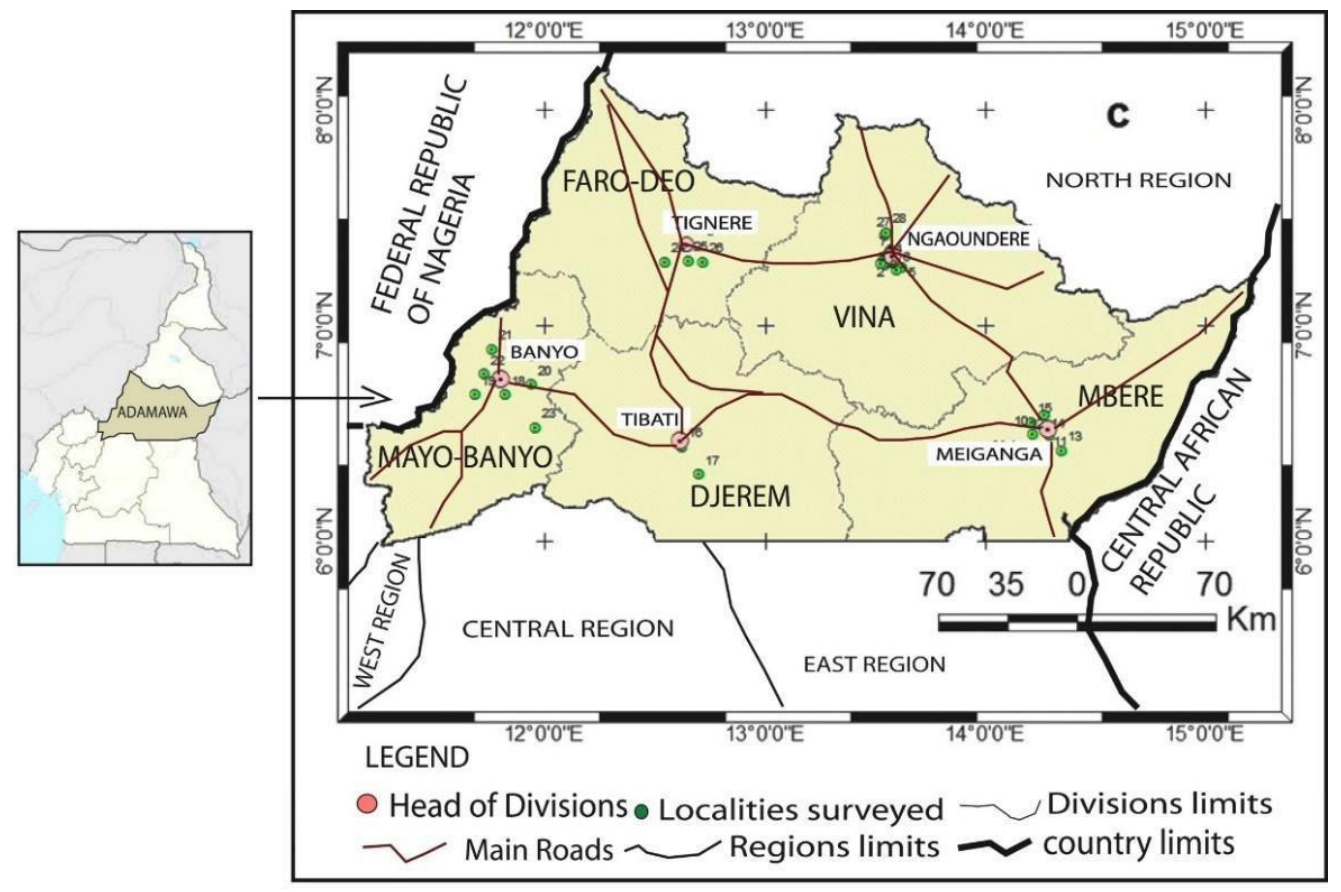

Fig.2 Integrated approach for the study of production practices and quality

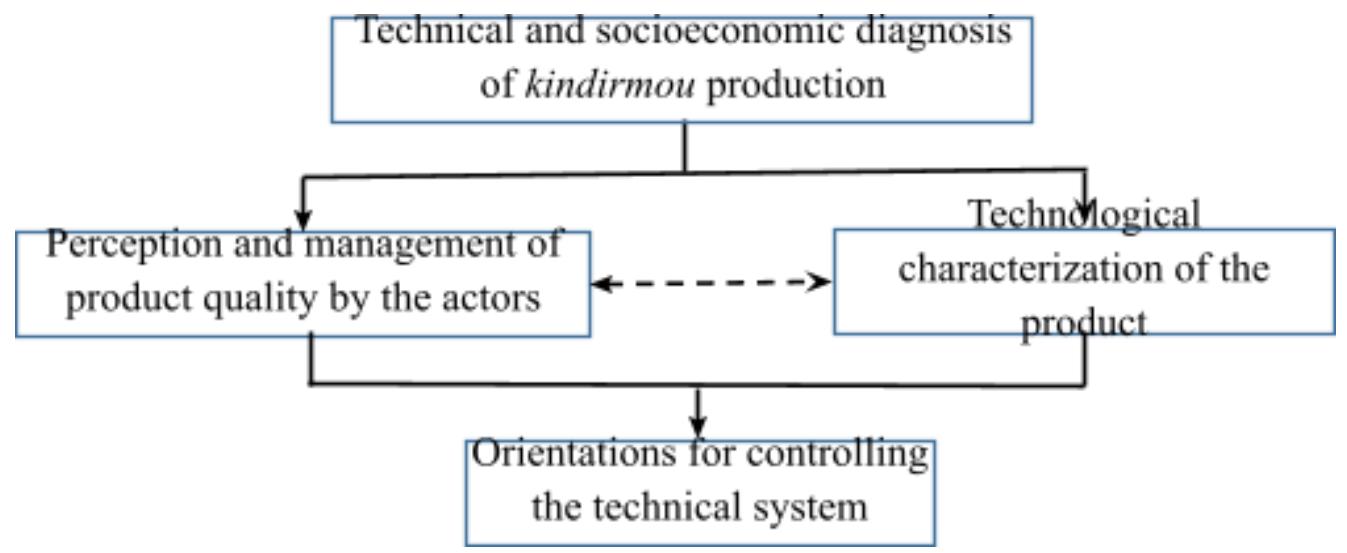


Fig.3 Gender distribution of actors in the production of kindirmou by ethnic groups (a) and by level of education (b) in the Adamawa Region of Cameroon.

(a)

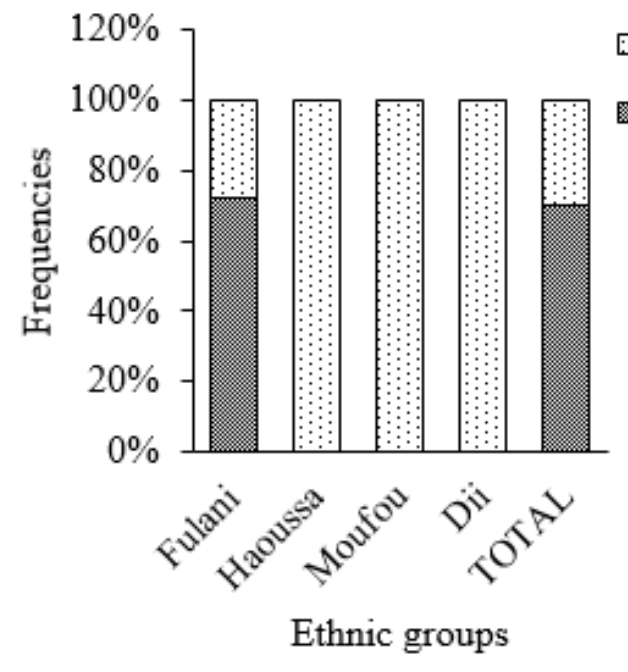

(b)

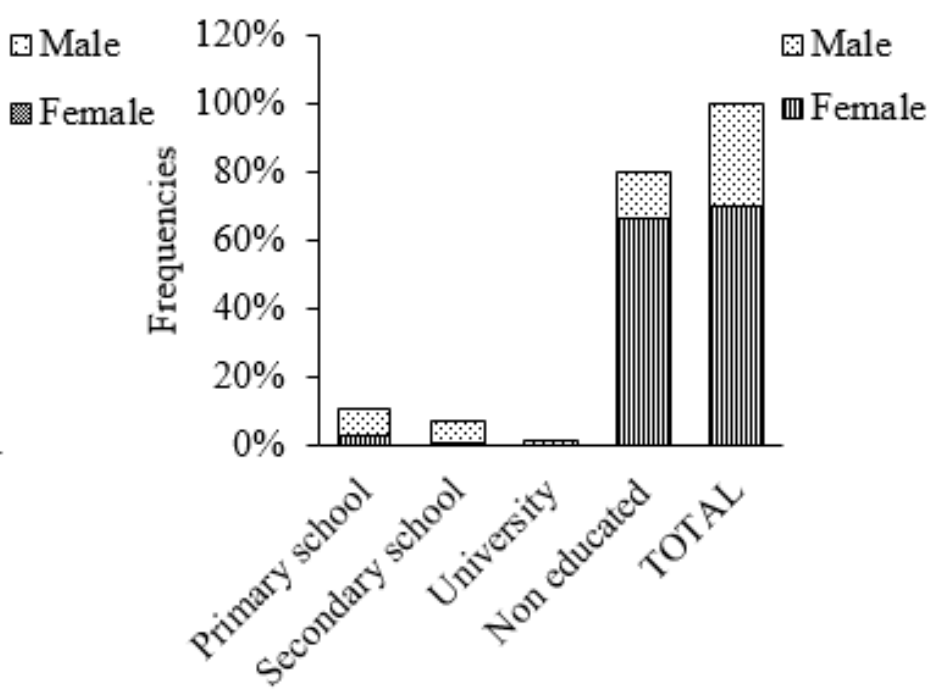

Education level

Fig.4 Spatial distribution of actors in the production of kindirmou by ethnic group

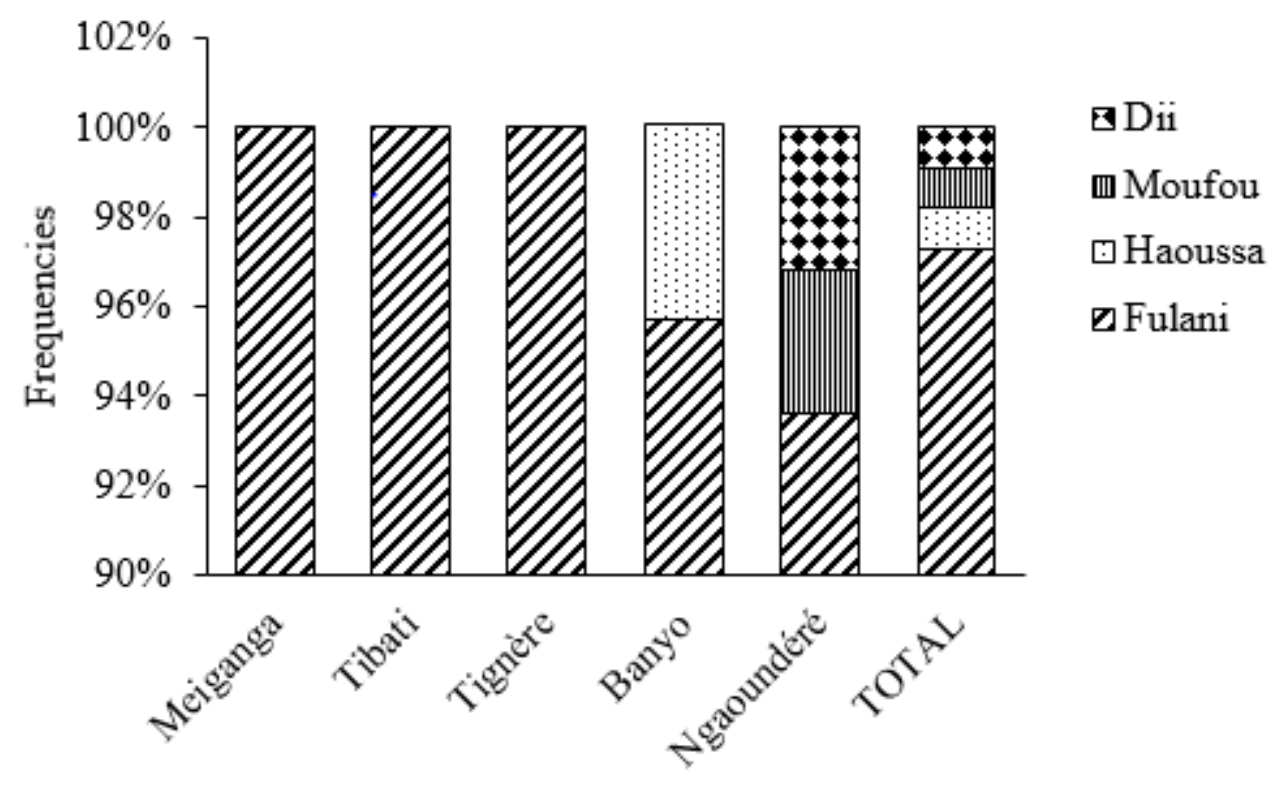

Localities 
Fig.5 Artisanal process diagram of kindirmou production

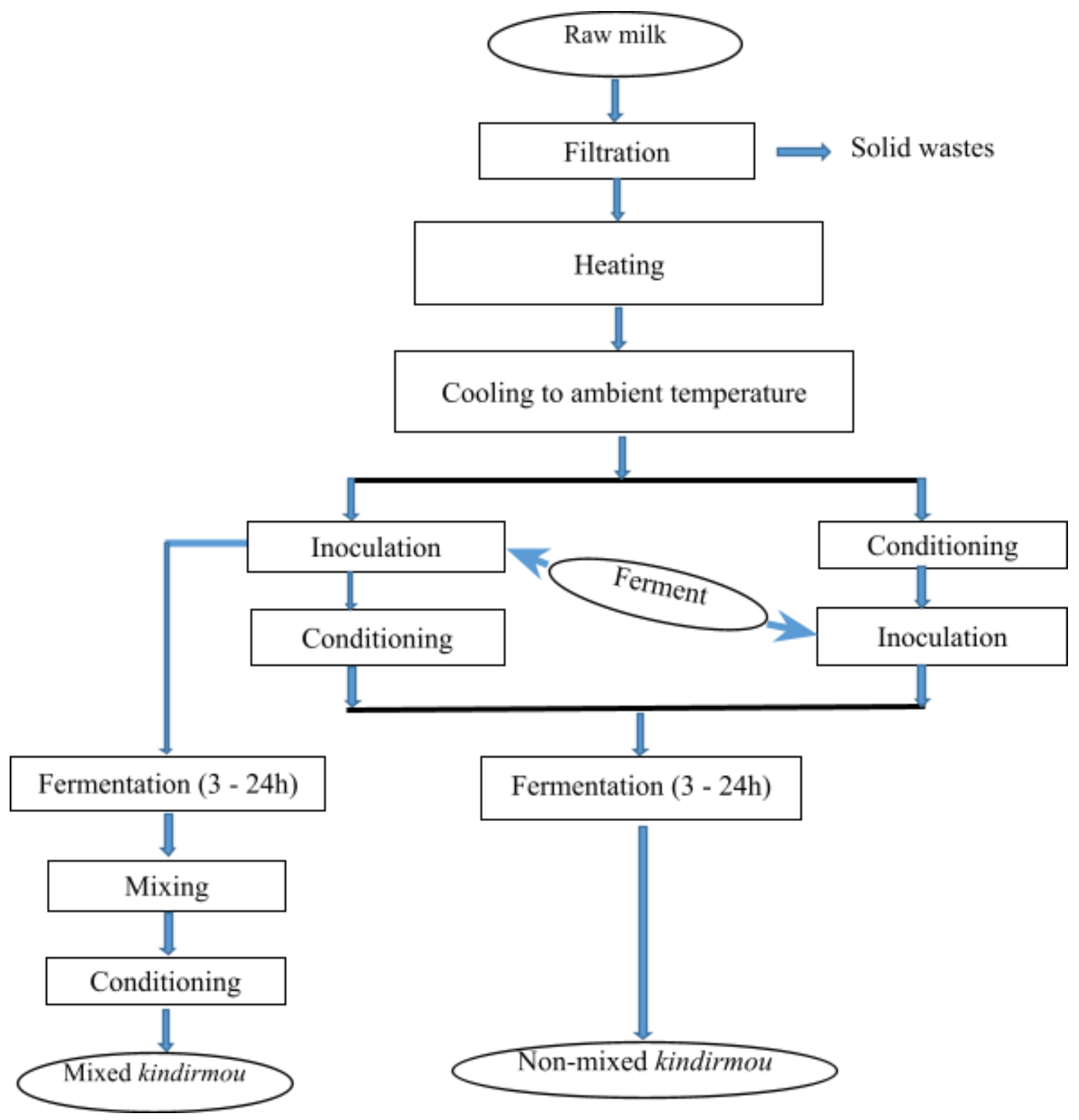


Fig.6 Methods of preparing the ferments used in the production of kindirmou

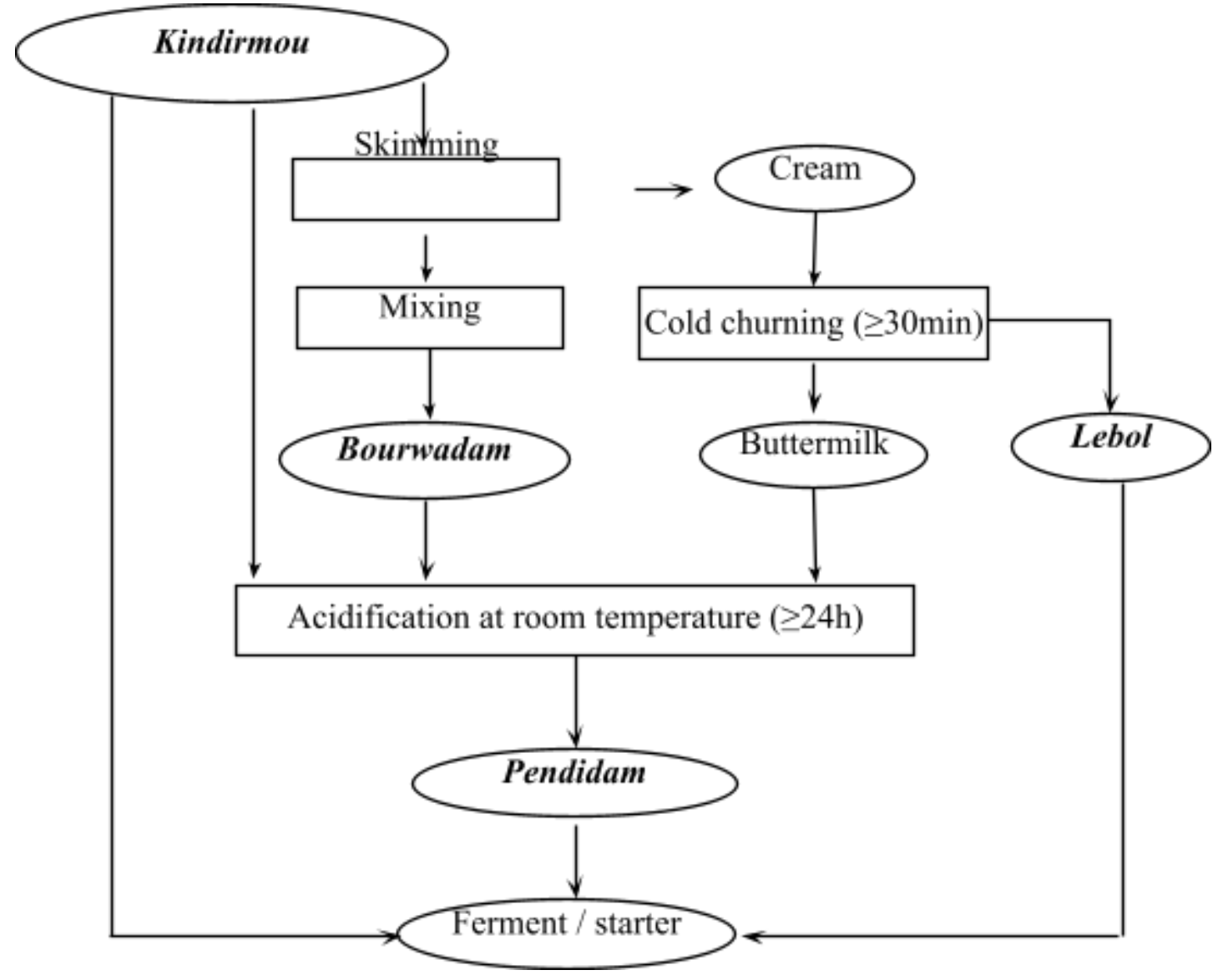

Fig.7 Quality attributes of kindirmou in production localities

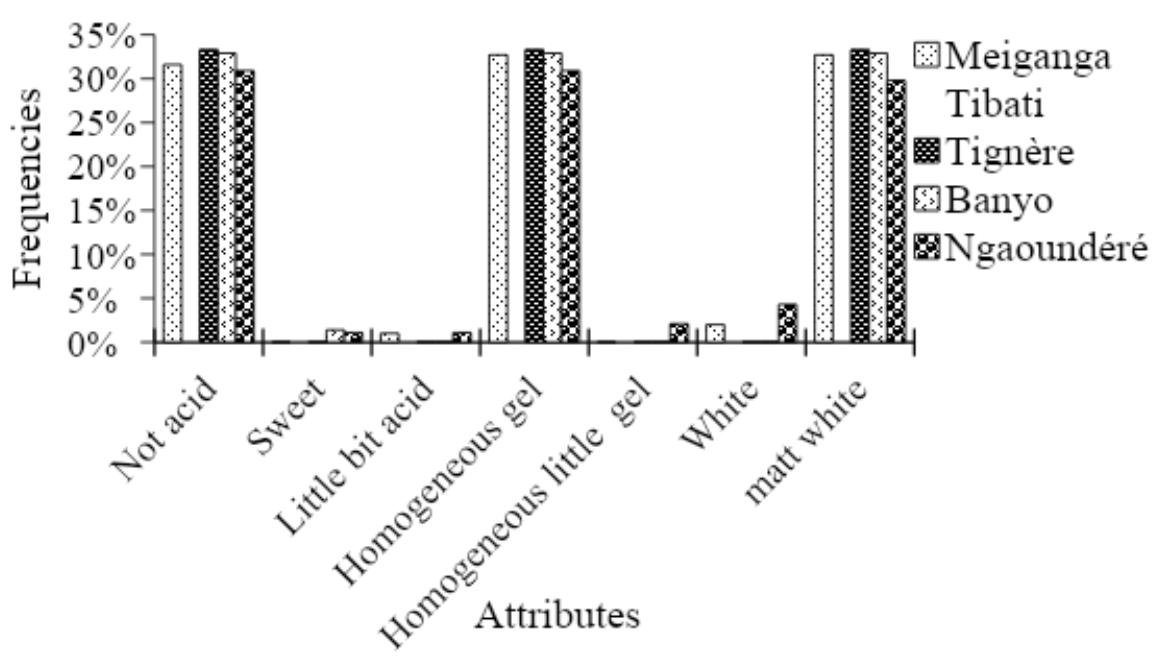


Fig.8 Characteristics of poor-quality kindirmou

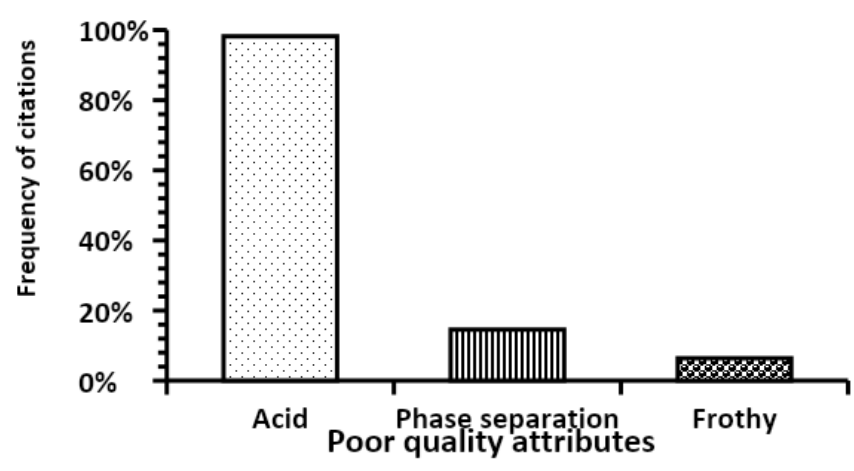

Fig.9 Comparative analysis of the fermentation management mode (type of ferment [ ], inoculation rate [-], fermentation time [ $\Delta]$ ) in the different production localities [0] of kindirmou in the Adamawa Region (Ft: fermentation time; Fr: fermentation rate)

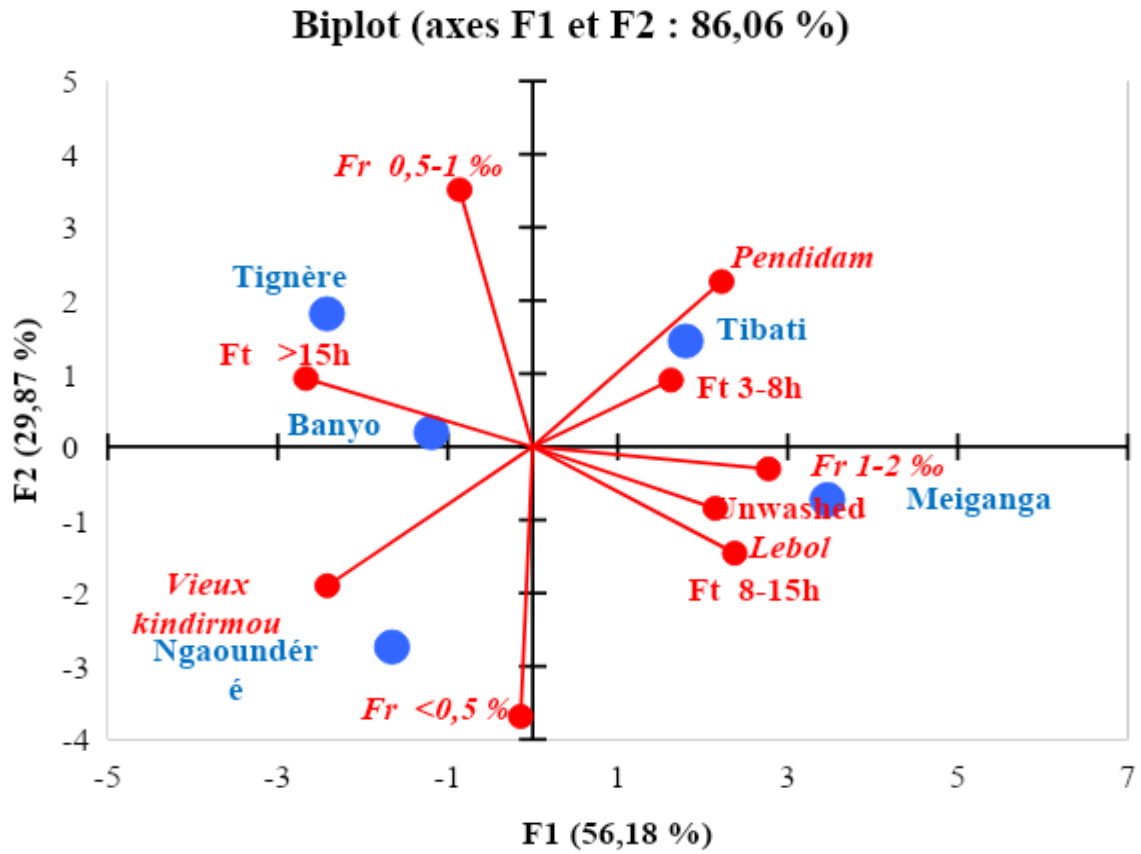

Heating the milk before processing and the relative attention paid to the dosage of ferments and the fermentation time can be considered, from the point of view of the actors, as forms of management of the risks of non-compliance of kindirmou. In this regard, if the systematic heating of milk is perceived by more than $90 \%$ of the actors as a constructive element of the quality of the product, in terms of the firmness of kindirmou, it nevertheless constitutes a factor of sanitation, although the temperature and the treatment times are excessive in some cases.

In addition, $70 \%$ of the actors claim to process the milk within 2 - 3 hours after milking, which is relatively comparable to 
the recommendations of the Codex Alimentarius (FAO, 2012), indicating a relative consideration, by the actors, of the need to avoid any risk of occurrence of negative attributes of product quality. In addition, the limited dosage of the ferment (0.5 to $1.75 \mathrm{ml}$ per liter of milk), in conjunction with the management of the fermentation time, meets the requirement of a non-acidic taste of kindirmou. The evaluation of the $\mathrm{pH}$ of kindirmou, a technological indicator of the perception of the acidity of the product, shows that all the products sampled from producers in the region have a value between 4.5 and 4.9 (Tab. 1) and confirms the values initially reported by Libouga et al., (2005) and Ngassam (2007). This range of $\mathrm{pH}$ values is compatible with those of firm fermented milks without whey exudation or phase separation (Bourdichon, 2012; Croguennec et al., 2008), as well as with the preferences of consumers of lowacid yogurts (Tamime et Robinson, 2007b; Loones, 1994). It should be noted that this $\mathrm{pH}$ of kindirmou is obtained with a ferment inoculation rate between 0.5 and $1.75 \mathrm{ml} /$ liter of milk, i.e. 0.5 to $1.75 \%$, which is relatively low compared to the range of $2-5 \%$ recommended for obtaining a bacterial population of the order of $107 \mathrm{CFU} / \mathrm{mL}$ (Clark et Plotka, 2004), values considered effective for obtaining fermented milk in 3 hours (Benbadis et al., 1998). The weak or non-acidic taste of kindirmou preferred by those involved in production and certainly by consumers, justifies the low inoculation rate applied by kindirmou producers which, however, has the effect of lengthening the latency time of the milk acidification process (Jones et al., 1992), a strategy adopted by producers to overcome the problems of management of fermentation time in relation to the quality of the product without refrigeration means.
For a given production locality, no significant difference appears in the $\mathrm{pH}$ of the kindirmou whatever the ferment used, whereas from one locality to another, the same ferment can lead to different $\mathrm{pH}$ values (Tab. 1). This influence of the locality of production on the acidity of kindirmou can be attributed to a variability in the management methods of the production process in the different localities, in this case the conditions of heat treatment (Temperature-time) and of fermentation (type of ferment, inoculation rate and fermentation time) of milk, or even the product's storage conditions (Luquet et Corrieu, 2005; Mahaut et al., 2005; AlonsoCalleja et al., 2002; Beal et al., 1999). Given that $90 \%$ of those involved in the production of kindirmou boil the milk before fermentation and that the nature of the ferment is not a factor in the variation of the $\mathrm{pH}$, the inoculation rate and the fermentation times seem to be considered as factors of construction of the quality of the product at the local level. In this regard, the comparative analysis of the fermentation management mode (nature of the ferment, inoculation rate, fermentation time) in the different localities (Fig. 9), makes it possible to group together the production areas according to two modes of management of fermentation practice:

The producers of Tignère, Ngaoundéré and Banyo are characterized by a majority use of old-kindirmou (generally from the production of the day before, therefore of relatively low acidity), at a relatively low inoculation dose $(0.5-1 \%)$, but a long fermentation time $(>15 \mathrm{H})$;

On the other hand, the producers of Tibati and Meiganga mainly use pendidam, a more acidic ferment, at an inoculation rate of 1-2 $\%$, and a relatively shorter fermentation time $(\leq 15 \mathrm{H})$. Note a particularity for Meiganga where, in addition, unwashed lebol is used. 
The characterization of the kindirmou production system has shown that, the application of Good Hygiene and Manufacturing Practices is not effective in all structures and fermentation conditions are not mastered. It therefore appears necessary to support the actors in this sector in the application of Good Hygiene and Manufacturing Practices and to formulate a ferment in order to control fermentation. Ultimately, kindirmou is a local dairy product with strong economic and nutritional potential that needs to be developed for the financial empowerment of stakeholders

\section{Declaration}

The authors did not receive support from any organization for the submitted work.

\section{Conflict of interest}

The authors have not stated any conflict of interest

\section{References}

Alonso-Calleja C., Carballo J., Capita R., Bernardo A. \& Garcia-Lopez M. L., 2002. Changes in the microflora of Valdeteja raw goats milk cheese throughout manufacturing and ripening. LWT 35, 222232. htps://doi.org/10.1006/fstl.2001.0842.

Balla A., 2011. Effets de quelques cryoprotecteurs sur la conservation d'une souche d'intérêt isolée à partir du lait camelin. Thème de Magistère. Université d'Ouargla, Algérie.

Beal C., Skokanova J., Latrille E., Martin N. \& Corrieu G., 1999. Combined effects of culture conditions and storage time on acidification and viscosity of stirred yogurt. Journal.of Dairy Science. 82, 673681. https://doi.org/10.3168/jds.S00220302(99)75283-5.

Benbadis L., Oudot E. \& De Villeroche J., 1996, Streptococus thermophilus strain, fermentation process using such strain and product obtained. Gervais Danone, assignee. European Patent NO WO 96/10627.

Bourdichon F., Casaregola S., Forrokh C., Frisva J. C., Gerds M. L., Hammes W. P., Harnett J.,

Boutrais J., 2006. Pastoralisme et aires protégées en Afrique de l'Ouest et de l'Est. In : Aubertin, C., F. Pinton \& E. Rodary (eds), Les aires protégées, zones d'expérimentation $d u$ développement durable : recueil des contributions. ATI seminar - Queyras Regional Natura Park France, 28-30. November 2006 https://www.documentation.ird.fr/hor/fdi:0 10043935\#.

Chatellier V., 2019. La planète laitière et la place de l'Afrique de l'Ouest dans la consommation, la production et les échanges de produits laitiers. In $3^{\text {èmes }}$ rencontres internationales sur «Le lait, vecteur de développement », 12-13 June 2019, Dakar, Sénégal. Accessed December 10, 2020. https://www6.inrae.fr/lait-vecteur developpement/Editions/2019

Clark S. \& Plotka V. C., 2004. Yoghurt and sour cream: operational procedures and processing equipment, pp 159-182. In Hui, Y. H., Meunier-Goddik, L., Åse Solvejg, H., Josephsen, J., Wai-Kit Nip, Stanfield, P.S., and Toldrà, F. (eds), Handbook of food and beverage fermentation technology. Marcel Dekker Inc. New York Basel.

Croguennec T., Jeantet R. \& Brulé G., 2008. Les Fondements Physico-chimiques de la Technologie Laitière. Technologie et Documentation. Lavoisier, Paris, 135 p.

Dairou S., Biyanzi P., Pallet D. \& Ndjouenkeu R., 2014. Traditional Production, Processing and Quality Attributes of Ziziphus mauritiana in Savannah Region of Cameroon. Journal of Scientific Research \& Reports, 3(5) : 686-699.

Duteurtre G., 2019. Les produits laitiers africains à l'épreuve de la libéralisation : Des traditions laitières en danger, un 
patrimoine à valoriser. In $3^{\text {èmes }}$ rencontres internationales sur «Le lait, vecteur de développement», 12-13 June 2019, Dakar, Sénégal. Accessed December $\quad 10, \quad 2020 . \quad \mathrm{h}$ ttps://www6.inrae.fr/lait-vecteurdeveloppement/Editions/2019.

Edima H. C., Awono E. T. \& Ndjouenkeu R., 2013. An Analysis of the Milk Quality in Cameroon. A Study in Adamawa Region. Journal of Scientific Research \& Reports 2(1), 337-346.

Edima H. C., Awono E. T., Biloa D. M., Tchoumkeu H. B. \& Etoa F-X., 2014. Evaluation of good hygienic practices on the production of kindirmou and lebol. International Journal of Current Microbiology and Applied Sciences 3(9): 249-253.

Essomba J. M., Dury S., Mbonji Edjenguèlè \& Bricas N., 2002. Permanences et changements dans la consommation des produits laitiers ; la « success story » des petites entreprises de transformation à Ngaoundéré, Cameroun, Pages 1-10. In "Food resources and food choices in the Lake Chad basin". $\mathrm{XI}^{\text {th }}$ International Colloquium Mega-Tchad, CNRS/University of Paris X-Nanterre (France).

FAO (Food agricultural Organization).et IDF (International Dairy Federation). 2012. Guide de bonnes pratiques en production laitière Directives FAO : Production et santé animales. 51pp.

FAO. (2007). Les bonnes pratiques d'hygiène dans la préparation et la vente des aliments de rue en Afrique.188 pages

Federighi M. Bactériologie alimentaire compendium d'hygiène des aliments. 2nd Ed. Economica Paris, pp 224-233.

Gran H. M., Mutukumira A. N., Weltlesen A., \& Narvhus J. A., 2002. Small holder dairy processing in Zimbabwe: the production of fermented milk products with particular emphasis on sanitation and microbiological quality. Food Control, 13, 161-168.
Guétat-Bernard H., 2015. Travail des femmes et rapport de genre dans les agricultures familiales : analyse des similitudes entre la France et le Cameroun. Revue Tiers Monde, 1(221), 89-106. https://www.cairn.info/revue-tiers-monde2015-1-page-89.htm.

Huys G., Laulund S., Ouwehand A., Powell I. B, Prajapati J. B., Seto Y., Schure E. T., Van Boven A., Vankerckhoven V., Zgoda A., Tuijtelaars S. \& Hansen E. B., 2012. Food fermentations : microorganisms with technological beneficial use. International. Journal. of Food Microbiology., 154(3), 87-97. ttps://doi.org/10.1016/j.ijfoodmicro.201 1.12.030.

Jans C., Meile L., Kaindi D. W. M., KogiMakau W., Lamuka, P., Renault P., Bonfoh,B., 2017. African fermented dairy products- Overview of predominant technologically important micro organisms focusing on African Streptococcus infantarius variants and potential future applications for enhanced food safety and security. International Journal of Food Microbiology, 250, 27-36. https://doi.org/10.1016/j.ijfoodmicro.2017. 03.012 .

Jiwoua C. \& Millière J. B., 1990. Lactic flora and Enterococci in cultured milk (Pendidam) manufactured in Adamaoua (Cameroon). Lait, 70, 475-486. https://doi.org/10.1051/lait:19905-637

Jones B. A., Satter L. D. \& Muck R. E., 1992. Influence of bacterial inoculant and substrate addition to lucerne and ensiled at different dry matter contents. Grass Forage Science, 47, 19-27. https://doi.org/10.1111/j.13652494.1992.tb02243.x.

Laithier C., Chatelin Y. M., David V., Tormo H., Lefrileux Y. \& Gauzere, Y., 2004, Facteurs de maîtrise de l'acidification dans les technologies fromagères fermières (caillé lactique) utilisant du lactosérum comme ferment. Rencontres Recherche Ruminants, 11, 95-98. 
Libouga D. G., Essia Ngang J. J. \& Halilou H., 2005. Qualité de quelques laits fermentés camerounais. Sciences des aliments 25, 53-56.

Libouga D. G., Womeni H. M. \& Bitjoka, L., 2002. Extrait des écorces de l'Ongokea gore: protéolyse et conservation. Journal of the Cameroon Academy of Sciences. 2, 89-150.

Loones A., 1994. Laits fermentés par les bactéries lactiques. In De roissart H. \& Luquet F. M. (eds), Bactéries lactiques : Aspects fondamentaux et technologique Vol 2, pp 135-154. Uriage Lorica, France.

Luquet F. M. \& Corrieu G., 2005. Bactéries lactiques et probiotiques. Technologie \& Documentation, Lavoisier. Paris 307p.

Mahaut M., Jeantet R., Brule G. \& Schuck P., 2005. Produits laitiers industriels, pp 140. Technology \& Documentation Lavoisier. France.

Metzger R., Centres J.M., Thomas L. \& Lambert J.C., 1995. Approvisionnement laitier des villes africaines. FAO, Rome, GRET, France. http://www.fao.org/3/V4870F/V4870F00.ht m\#Contents.

Ndjouenkeu R. \& Cerdan C., 2003. Impact de l'innovation technologique sur l'amélioration des systèmes alimentaires du Nord Cameroun. In Brouwer, I. D., Traoré A. S. \& Trèche S. (eds), Voies alimentaires d'amélioration des situations nutritionnelles en Afrique de 1'Ouest, pp 633-646. Proceedings of the $2^{\text {nd }}$ International workshop, Ouagadougou, Burkina Faso, 23 - 28 November 2003, $1134 \mathrm{p}$.
Ndjouenkeu R., 2018. Cassava in Central and Western Africa: Postharvest Constraints and Prospects for Research and Market Development, pp 199-217. In Waisundara, V. (ed), Cassava. Intech Open Science, $304 \quad$ p. http://dx.doi.org/10.5772/intechopen.71507

Nduko J. M., Matofari J. W., \& Nandi Z. O., 2017. Spontaneously fermented kenyan milk products: A review of the current state and future perspectives. African Journal of Food Science, 11(1),1 11. https://doi.org/10.5897/AJFS2016.1516

Ngassam T.C., 2007. Contribution à l'étude des caractéristiques microbiologiques des laits fermentés artisanaux au Sénégal : cas de la zone des Niayes. Veterinary Medicine Thesis, Dakar, 109 pages.

Redlingshofer B. \& Soyeux A., 2010. Cultures des laits du monde. Le Courrier de l'environnement de l'INRA, 59(59), 93-96. (2010). https://hal.archives-ouvertes.fr/hal01211502.

Sow S. A., 2005. Le lait, patrimoine des Peuls pasteurs du Niger : pratiques alimentaires, représentations et usages non alimentaires chez les Gaawoo'be du Gourma, pp 419-442. In Cormier-Salem M. C., Juhé-Beaulaton D., Boutrais J. \& Roussel B. (eds), Patrimoines naturels au Sud : Territoires, identités et stratégies locales. IRD éditions Colloques et Séminaires, Paris, France, $551 \mathrm{p}$.

Tamime A. Y. \& Robinson R. K., 2007. Processing plants and equipment. In Tamime and Robinson's Yoghurt, Science and technology (Third edition), pp 162283. Wood head Publishing.

\section{How to cite this article:}

Esther Biaton Njeufa, Hélène Carole Edima and Robert Ndjouenkeu. 2021. Characterization of Technical Production System of Kindirmou, a Fermented Local Milk Product from Cameroon. Int.J.Curr.Microbiol.App.Sci. 10(06): 10-28. doi: https://doi.org/10.20546/ijcmas.2021.1006.002 